\title{
Nefropati Diabetik pada Anak
}

\author{
Sudung O. Pardede \\ Departemen Ilmu Kesehatan Anak FKUI RS. Dr Cipto Mangunkusumo, Jakarta
}

\begin{abstract}
Abstrak
Nefropati diabetik adalah nefropati akibat diabetes melitus yang ditandai dengan penurunan fungsi ginjal yang progresif, hipertensi, proteinuria, dan tanda-tanda insufisiensi ginjal kronik lainnya. Diperkirakan pada 30\%-50\% pasien diabetes melitus tergantung insulin (DMTI) akan terjadi kelainan ginjal setelah 5-15 tahun kemudian. Deteksi nefropati diabetik dilakukan dengan pemeriksaan mikroalbuminuria. Tata laksana nefropati diabetik terdiri dari pengobatan mikroalbuminuria, menanggulangi hipertensi, dan tata laksana diabetes melitus. Pemberian penghambat angiotensin converting enzyme dan pengendalian tekanan darah akan memperlambat progresivitas nefropati diabetik. Penghambat angiotensin converting enzyme akan mengurangi kerusakan glomerulus dengan mempertahankan tekanan kapiler glomerulus dalam keadaan normal. Tata laksana diabetes melitus meliputi pengontrolan gula darah, perbaikan kebiasaan hidup, pemberian insulin. (Sari Pediatri 2008;10(1):8-17).
\end{abstract}

Kata Kunci: diabetes melitus tergantung insulin (DMTI), nefropati diabetik, mikroalbuminuria, penghambat angiotensin converting enzyme (ACE).

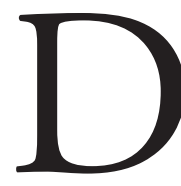
iabetes melitus adalah penyakit gangguan metabolik energi akibat defisiensi insulin atau defisiensi kerja insulin, yang ditandai perubahan metabolisme karbohidrat, protein, dan lemak. Insulin diperlukan untuk pemasukan glukosa ke dalam sel lemak dan otot. Diabetes melitus dibedakan menjadi 2 tipe yaitu diabetes melitus tipe I atau diabetes melitus tergantung

Alamat Korespondensi:

Dr. Sudung O. Pardede, Sp.A(K). Divisi Nefrologi. Departemen Ilmu Kesehatan Anak Fakultas Kedokteran Universitas Indonesia Jl. Salemba no. 6, Jakarta 10430. Telepon: 021-3915179. Fax.021-390 7743. insulin (DMTI, insulin dependent diabetes mellitus, IDDM) dan diabetes melitus tipe II atau diabetes melitus tidak tergantung insulin (DMTTI, insulin nondependent diabetes mellitus, INDDM). DMTI adalah diabetes melitus yang terjadi karena defisiensi produksi insulin atau insulin tidak disekresi karena kerusakan sel beta pankreas oleh proses autoimun, sehingga pasien sangat tergantung pada insulin untuk kelangsungan hidupnya. Penyebab DMTTI adalah diabetes melitus yang terjadi sebagai akibat resistensi organ atau jaringan (seperti otot skeletal, hati, dan jaringan lemak) terhadap insulin. Kejadian DMTI merupakan diabetes melitus yang paling sering ditemukan pada anak dan remaja, sedangkan DMTTI lebih sering ditemukan pada dewasa. ${ }^{1-4}$ 
Nefropati diabetik adalah kompikasi yang ditandai dengan penurunan fungsi ginjal yang progresif dan kelainan sistemik seperti proteinuria, hipertensi, dan tanda-tanda insufisiensi ginjal kronik lainnya. Prevalensi gagal ginjal terminal (GGT) diabetik pada anak berumur 0-19 tahun sekitar 15,2\% per 1 juta populasi dan insidens diabetes melitus pada anak hingga 19 tahun adalah $16,7 \%$ per 100.000 populasi. $^{2}$

Di Amerika Serikat, nefropati diabetik merupakan penyebab terbanyak penyakit ginjal stadium akhir. Nefropati diabetik terjadi pada 20-35\% pasien DMTI dan pada $8-20 \%$ pasien DMTTI, dalam waktu 5-20 tahun setelah awitan. Meningkatnya risiko kematian pada DMTI disebabkan oleh nefropati diabetik, dan mencapai $50 \%$ dari sebab kematian. Risiko terjadinya nefropati diabetik akan meningkat seiring dengan lamanya perjalanan penyakit, keberhasilan pengendalian metabolik, dan predisposisi genetik terhadap hipertensi. ${ }^{1,3}$

\section{Ekskresi albumin}

Dalam keadaan normal, ekskresi albumin urin kurang dari $20 \mu \mathrm{l} / \mathrm{menit}$ atau kurang dari $30 \mathrm{mg} /$ hari. $^{1-5}$ Mikroalbuminuria berarti ekskresi albumin $>20-200$ $\mathrm{ug} / \mathrm{menit}$. Albuminuria signifikan atau nefropati overt adalah proteinuria dipstik positip yang berarti ekskresi albumin $>200 \mu \mathrm{g} / \mathrm{menit}$ atau $>300 \mathrm{mg} / \mathrm{hari}^{1-5}$ Kadar albuminuria $12-20 \mu \mathrm{g} /$ menit masih dalam batas normal, tetapi jumlah ini tidak lazim pada orang sehat. Pada DMTI, kadar albuminuria $12-20 \mu \mathrm{g} /$ menit merupakan tanda akan menjadi mikroalbuminuria persisten. ${ }^{3}$ Pemeriksaan mikroalbuminuria dengan radioimmunoassay merupakan pemeriksaan yang paling akurat. $^{2}$

\section{Patogenesis}

Kejadian penyakit ginjal stadium akhir pada nefropati diabetik tidak dapat dicegah, tetapi dapat diperlambat dengan terapi yang adekuat. ${ }^{3}$ Ada beberapa faktor risiko terjadinya nefropati pada diabetes melitus, seperti peningkatan laju filtrasi glomerulus (LFG) atau hiperfiltrasi glomerulus, hipertensi sistemik dan atau glomerular, disfungsi vaskular (endotelial), kontrol metabolik yang buruk yang ditandai dengan peningkatan hemoglobin glikosilat atau HbA1C, perubahan biokimiawi pada membran basalis glomerulus (MBG) yang menyebabkan peningkatan permeabilitas vaskular dan kerusakan struktur jaringan, faktor genetik, dan faktor diet (diet tinggi protein, natrium, dan lemak). ${ }^{1,2}$

Apabila pada nefropati diabetik sudah ditemukan mikroalbuminuria atau penurunan LFG, akan terjadi perubahan histopatologis yang progresif pada MBG dan mesangium ginjal, dan terdapat peningkatan kolagen tipe IV dan $\mathrm{V}$, protein serum, dan laminin di dalam MBG yang menebal, serta perubahan pada proteoglikan heparan sulfat pada MBG. Perubahan pada MBG ini akan mengawali serangkaian perubahan pada MBG yang menyebabkan proteinuria dan berkurangnya daerah permukaan filtrasi glomerulus. ${ }^{2}$ Terjadinya nefropati pada diabetes melitus disebabkan oleh beberapa faktor seperti kelainan hemodinamik ginjal, adanya predisposisi genetik, dan kelainan metabolisme.

\section{Hemodinamik ginjal}

Resistensi arteriol preglomerulus dan pascaglomerulus serta resistensi tekanan darah sistemik menentukan resistensi kapiler glomerulus. Kombinasi hipertensi sistemik dan dilatasi (penurunan resistensi) arteriol aferen atau kontraksi arteriol eferen akan menyebabkan hipertensi glomerulus. Peningkatan resistensi vaskular intrarenal akan menyebabkan kerusakan glomerulus. Dalam keadaan normal, tonus vaskular diatur oleh produksi vasokonstriktor (endotelin, angiotensin II, prostaglandin $\mathrm{H}_{2}$ platelet activating factor, platelet-derived growth factor) dan mediator vasodilator seperti endotheliumderived relaxing factor (atau nitric oxide) dan prostasiklin. ${ }^{2}$ Hiperfiltrasi glomerulus terjadi karena peningkatan LFG akibat peningkatan aliran darah dan tekanan kapiler glomerulus, dan berperan penting dalam patogenesis dan progresivitas nefropati diabetik. ${ }^{1-4}$ Keadaan diabetik seperti hiperglikemia, insulinopenia, dan akumulasi sorbitol akan menyebabkan peningkatan LFG meskipun mekanismenya belum diketahui. Pada DMTI stadium dini, hiperfiltrasi glomerulus didapatkan pada $25 \%-50 \%$ pasien ${ }^{2,3}$

\section{Predisposisi genetik}

Predisposisi genetik sangat berperan dalam terjadinya nefropati pada diabetes melitus. ${ }^{1-5}$ Risiko terjadinya nefropati pada pasien dengan keluarga 


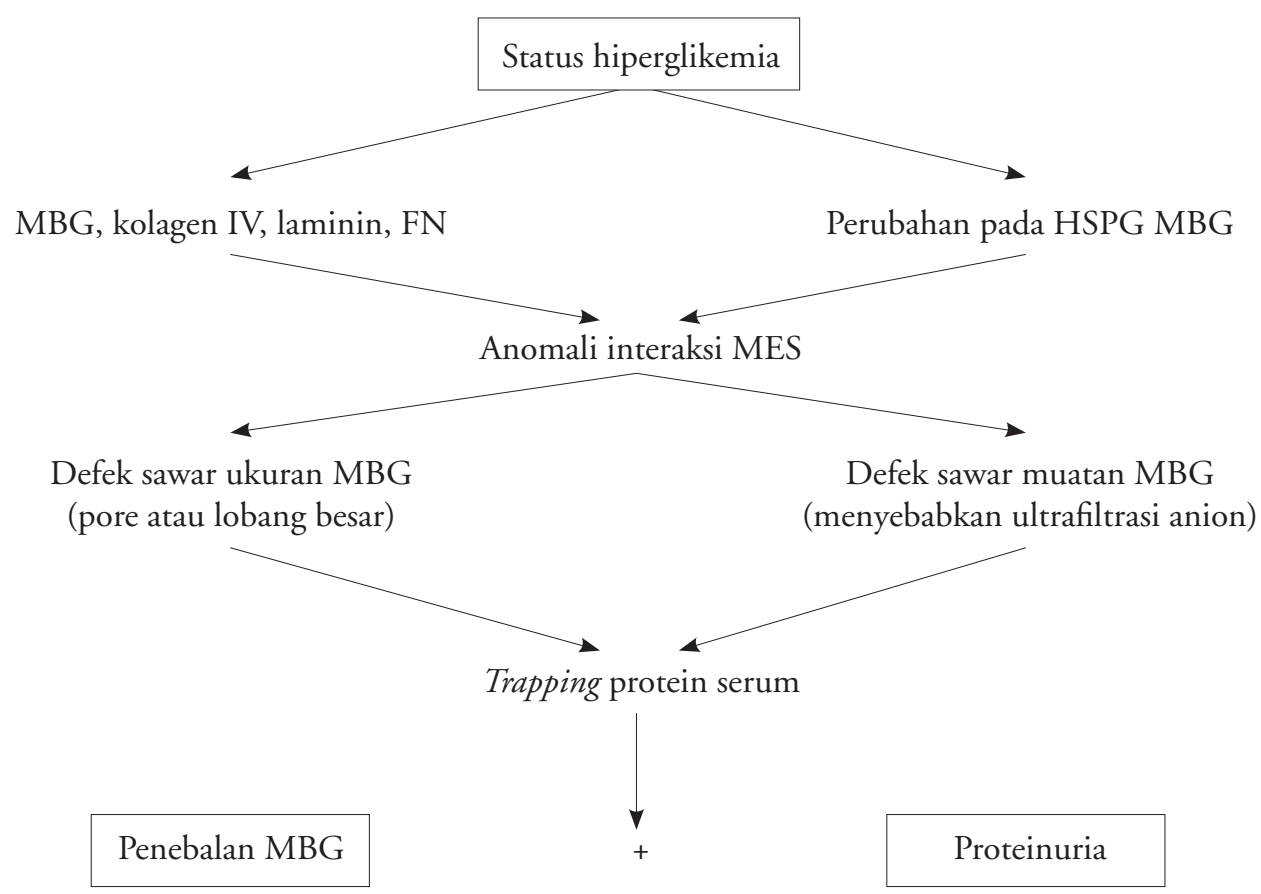

Gambar 1. Algoritme hipotetis kelainan biokimia pada MBG nefropati diabetik

Ket: MES: matriks ekstraselular, MBG: membran basalis glomerlus, FN: fibronektin, HSPG: heparan sufat proteoglikan (dikutip : Feld LG. Diabetic nephropathy. Dalam: Avner ED, Harmon WE, Niaudet P, Pediatric Nephrology, edisi ke-5, Philadelphia, Lippincott Williams \& Wilkins, 2004:h.931-9.

nefropati adalah $72 \%$ atau sekitar $50 \%$ lebih tinggi dibandingkan dengan pasien tanpa anggota keluarga yang menderita nefropati (25\%). Pada pasien dengan neuropati atau retinopati, kemungkinan terjadinya nefropati sekitar $25 \%$, sedangkan pada nefropati diabetik kemungkinan terjadinya neuropati atau retinopati $>85 \% .^{2}$ Faktor etnik juga berpengaruh terhadap kelainan ginjal, ${ }^{3}$

Beberapa gen diduga berperan dalam patofisiologi nefropati diabetik. Gen ACE (angiotensin-convertingenzyme) berperan dalam terjadinya nefropati diabetik, meskipun ada penelitian yang tidak dapat menunjukkan hubungan antara gen ACE dengan risiko nefropati diabetik atau dengan penurunan LFG pada DMTI dan DMTTI. ${ }^{3}$ Pada DMTI, risiko terjadinya nefropati diabetik berkaitan dengan haplotipe pada lokus ACE, sedangkan pada DMTTI, terdapat hubungan antara gen renin-angitensin-system (RAS) dan meningkatnya ekskresi albumin dalam urin. Pada region yang mempunyai gen ACE dan angiotensinogen, lokus tidak mempunyai kaitan dengan nefropati diabetik sedangkan region yang mengandung lokus reseptor angiotensin II tipe 1 mempunyai kaitan dengan nefropati diabetik. ${ }^{1-4}$

Penelitian analisis meta membuktikan adanya hubungan antara D allele dengan DMTI dan DMTTI. Gen polimorfis renin, endothelial nitric oxide synthetase, aldose reduktase, PC-1, atrial natriuretic peptide, apolipoprotein E, dan protein core heparan sulfate mempunyai hubungan dengan nefropati diabetik. Berbagai gen lain juga sudah diteliti, tetapi hubungannya dengan nefropati diabetik belum semuanya jelas, seperti gen kolagen tipe IV, matrix metalloproteinase-9 (MP-9), reseptor endotelin dan endotelin A, transforming growth factor $\beta$ (TGF-ß1), plasminogen activator inhibitor-1, interleukin-1, interleukin-1 reseptor antagonist, protein $\mathrm{G}, \mathrm{B}_{3}$ adrenergic receptor, hepatocyte nuclear factor 1, methylenetetrahydrofolate reductase, kallikrein, Werner's syndrome helicase, gen reseptor bradikinin $\beta_{2}$, gen paraoxonase, dan gen insulin. ${ }^{3}$ 


\section{Metabolisme atau jalur biokimiawi}

Kelainan ginjal pada nefropati diabetik terutama disebabkan penimbunan komponen matriks ekstraselular (MES, extracellular matrix, ECM) seperti kolagen, tenascin, dan fibronektin. Penimbunan MES pada MBG merupakan penyebab ekspansi mesangium serta ekspansi interstitial, dan terjadi karena ketidakseimbangan antara sintesis dan degradasi komponen MES. Tidak semua komponen MES ginjal berubah pada nefropati diabetik. Rantai $\alpha 3$ dan $\alpha 4$ kolagen tipe IV akan menetap atau meningkat pada MBG sedangkan rantai $\alpha 1$ dan $\alpha 2$ kolagen tipe IV menurun pada dinding kapiler dan matriks mesangium. ${ }^{3}$

Hipotesis utama terjadinya komplikasi diabetik adalah, a. Peningkatan aktivitas faktor pertumbuhan (growth factor) seperti TGF- $\beta$, growth hormone, insulin-like growth factor (IGF), vascular endothelial growth factor (VEGF), b. Aktivasi protein kinase C (PKC), c. Aktivasi sitokin seperti renin, angiotensin, endotelin, bradikinin, d. Peningkatan pembentukan advanced glycation end products AGEs), e. Peningkatan aktivitas jalur aldose reduktase, f. Pembentukan reactive oxygen species (ROS), dan g. Perubahan metabolisme proteoglikan glomerulus. ${ }^{3}$

\section{a. Growth factors}

1. Transforming growth factors

Transforming growth factors (TGF- $\beta 1$, TGF- $\beta 2$, TGF- $\beta 3$ ) dan reseptornya terdapat pada semua sel glomerulus dan sel tubulus proksimal. Sel epitel dan mesangium glomerulus yang terpapar dengan TGF- $\beta$ akan meningkatkan sintesis protein MES, menurunkan sintesis MMP (matrix metalloproteniase), dan meningkatkan produksi TIMP (tissue inhibitors of MMPs). Mitogenactivated protein kinases (MAPK) mungkin berperan dalam glucose-induced TGF- $\beta$ yang memediasi peningkatan produksi MES dalam sel mesangium. TGF- $\beta-1$ akan merangsang pengambilan glukosa dengan meningkatkan transporter glukosa (GLUT1) dalam sel mesangium. Konsentrasi TGF- $\beta 2$ dan reseptor TGF- $\beta$ tipe II juga meningkat pada diabetes. Antibodi netralisasi terhadap TGF- $\beta-1$, TGF- $\beta-2$, dan TGF- $\beta-3$ ginjal akan membatasi peningkatan TGF- $\beta-1$, reseptor TGF- $\beta$ tipe II, kolagen IV, mRNA fibronektin, dan hipertrofi glomerulus. Pengobatan dengan penghambat ACE (enalapril) akan menurunkan reseptor TGF- $\beta$ tipe I, II, dan III glomerulus tanpa ada perubahan dalam isoform TGF- $\beta$. Penghambat ACE dapat mencegah peningkatan urinary albumin excretion rate (UAER) dan mencegah hipertrofi ginjal, serta mengatur sistem TGF- $\beta$ ginjal melalui penurunan reseptor TGF- $\beta .{ }^{3}$

2. Growth hormone dan insulin-like growth factor

Diabetes melitus dapat menyebabkan penurunan produksi IGF-1 oleh hepar sehingga kadar IGF-1 serum dan sekresi growth hormone turun, yang akan menstimulasi jalur IGF-1 lokal jaringan (seperti IGF-1 ginjal) dan menginduksi proliferasi sel mesangium. Penelitian menunjukkan bahwa pada sel mesangium tikus dengan diabetik non obese terjadi peningkatan sekresi IGF-1 dan penurunan aktivitas MMP-2 yang menyebabkan akumulasi MES glomerulus. Akumulasi IGF-1 ginjal dan hipertrofi ginjal dipengaruhi oleh glikemia. Akumulasi IGF-1 ginjal ini lebih disebabkan oleh perub ahan reseptor IGF-1 ginjal dan IGF-1 binding protein dibandingkan dengan meningkatnya produksi IGF-1 ginjal. Analog somatostatin dan antagonis reseptor growth hormone dapat mencegah peningkatan kadar mRNA protein pengikat IGF ginjal, IGF-1 ginjal, dan hipertrofi ginjal. ${ }^{3}$

\section{Vascular endothelial growth factor} Vascular endothelial growth factor (VEGF) merupakan mitogen poten terhadap sel endotel vaskular dan regulator penting dalam angiogenesis terjadinya retinopati proliferatif pada diabetes melitus. Dalam keadaan normal, VEGF terdapat pada glomerulus dan sel epitel tubulus, sedangkan reseptor VEGF tipe 2 terdapat pada sel endotel glomerulus dan sel interstitial kortikal. Mechanical stretch pada sel mesangium dapat menginduksi produksi VEGF yang berkaitan dengan kelainan hemodinamik glomerulus. ${ }^{3}$ VEGF akan meningkat dalam glomerulus pasien diabetes mellitus akibat hiperglikemia yang diinduksi aktivasi PKC, dan meningkatkan permeabilitas glomerulus dan albuminuria. Permeabilitas glomerulus berkurang oleh inhibisi PKC. ${ }^{2}$ Hipoksia merupakan stimulator kuat terhadap VEGF. Angiotensin II menstimulasi VEGF pada sel mesangium dan glukosa menstimulasi VEGF pada sel otot polos. ${ }^{3}$ 
4. Epidermal growth factor

Epidermal growth factor (EGF) disintesis di ginjal. Mesangium, tubulus, dan sel interstitial glomerulus mempunyai reseptor terhadap peptida ini. EGF merangsang proliferasi sel tubulus dan menyebabkan hipertrofi ginjal pada diabetes melitus stadium dini. EGF juga mempengaruhi sintesis MES dan perubahan protein MES sehingga terjadi nefropati diabetik. ${ }^{3}$

\section{b. Protein kinase $\mathbf{C}$}

Pada hiperglikemia dan diabetes melitus, terjadi peningkatan sintesis diasilgliserol (DAG) dari fosfatidil kholin oleh enzim fosfolipase D. Selanjutnya DAG akan mengaktivasi protein kinase C (PKC). Akumulasi DAG dan aktivasi PKC menyebabkan perubahan struktur dan permeabilitas glomerulus. Aktivasi PKC akan mempengaruhi inducible nitric oxide dan menyebabkan ekspansi mesangium, meningkatkan TGF- $\beta$ dan aktivitas mitogenactivated protein kinases (MAPK), serta menyebabkan vasodilatasi glomerulus., ${ }^{2,3}$

Meskipun terdapat hubungan antara PKC dan TGF- $\beta$, namun kerja TGF- $\beta$ tidak dimediasi oleh PKC. ${ }^{3}$ Aktivasi DAG kinase akan menurunkan aktivitas PKC dan menyebabkan restorasi hemodinamik ginjal., ${ }^{2,3}$ Inhibisi PKC akan menurunkan TGF- $\beta$, menurunkan ekspansi mesangium dan albuminuria. ${ }^{2}$

\section{c. Aktivitas sitokin}

- Prorenin dan renin

Hampir semua renin berasal dari ginjal dan prorenin terutama diproduksi di ginjal. Pada diabetes melitus dengan komplikasi mikrovaskular, kadar prorenin cenderung meningkat sedangkan kadar renin biasanya normal atau turun. Kadar prorenin lebih tinggi pada pasien dengan mikroalbuminuria dibandingkan dengan nonmikroalbuminuria. Hal ini menunjukkan bahwa prorenin berperan dalam terjadinya nefropati. Peningkatan produksi prorenin oleh aparatus juxtaglomerulus diikuti oleh meningkatnya aktivitas aparatus juxtaglomerulus lainnya seperti produksi TGF- $\beta$, dan berkaitan dengan kelainan MES glomerulus. Peningkatan prorenin plasma dapat digunakan sebagai prediktor terhadap progresivitas nefropati pada DMTI dan DMTTI. $^{3}$
- Angiotensin II

Angiotensin II merangsang proliferasi sel mesangium melalui aktivasi TGF- $\beta$. Sel mesangium yang terpapar dengan angiotensin II menyebabkan peningkatan TGF- $\beta$ dan mestimulasi sintesis MES. $^{3}$

\section{d. Advanced glycosylation end products}

Salah satu efek metabolik diabetes melitus adalah reaksi non enzimatik antara glukosa dengan amino bebas, lemak, atau asam nukleat. Interaksi ini dikenal dengan reaksi Maillard yang diakselerasi oleh hiperglikemia. Produk reaksi Maillard akan menyebabkan ikatan intermolekul dan intramolekul serta pembentukan AGEs. Pada diabetes melitus, beberapa protein seperti hemoglobin, albumin, low density lipoprotein $(L D L)$, protein membran eritrosit, dan kristalin lensa mengalami glikosilasi nonenzimatik dan menyebabkan perubahan psikokemikal. ${ }^{3}$

Pengendalian hiperglikemia yang buruk merupakan faktor penyebab terjadinya nefropati diabetik dan berkaitan dengan akumulasi advanced glycosylation end products (AGEs). Produk AGEs dibentuk di matriks vaskular dan dapat membatasi vasodilatasi melalui peranan endothelium-derived relaxing factor, ${ }^{2,3}$ akan diubah menjadi glycated AGEs yang ireversibel, dan reaksinya dengan reseptor AGE (RAGE) pada pembuluh darah dan ginjal pasien diabetes melitus dapat menyebabkan kerusakan ginjal dengan meningkatkan sintesis kolagen membran basalis dan matriks mesangium, meningkatkan permeabilitas vaskular, dan meningkatkan sekresi faktor pertumbuhan. Hal ini menyebabkan hipertrofi glomerulus dan glomerulosklerosis. Produk AGEs berperan juga dalam aterosklerosis diabetik melalui aktivasi selular dan inflamasi, pelepasan sitokin dan faktor pertumbuhan, peningkatan permeabilitas matriks vaskular dan endotel. ${ }^{2,3}$ Peningkatan AGEs merangsang sintesis growth factor seperti IGF-I dan TGF- $\beta$.

Kelainan utama glomerulus pada diabetes melitus adalah ekspansi mesangium akibat peningkatan MES. Pemaparan terhadap glikosilat MES akan menyebabkan peningkatan produksi MES sel mesangium. Dampak AGEs dihambat oleh penghambat AGE seperti aminoguanidin dan OPB 9195 yang menurunkan aktivitas kolagen IV, laminin, VEGF, TGF- $\beta$, dan platelet-derived growth factor, dan menyebabkan berkurangnya proliferasi glomerulus dan permeabilitas 
kapiler ${ }^{2}$ Aminoguanidin dapat memperbaiki penebalan MBG. $^{3}$

\section{e. Aldose reductase}

Aldose reduktase adalah enzim yang mengkatalisasi reduksi glukosa menjadi sorbitol, yang berperan dalam terjadinya nefropati diabetik dan komplikasi mikrovaskular lainnya. Aldose reduktase terdapat pada semua jaringan target komplikasi diabetik, termasuk lensa, sel perisit dinding kapiler retina, ginjal, endotel vaskular, dan saraf perifer (sel Schwann). Peningkatan aktivitas aldose reduktase akan menyebabkan akumulasi sorbitol yang akan diubah menjadi fruktosa oleh enzim sorbitol dehidrogenase, dengan menggunakan nikotinamid adenin dinukleotida $\left(\mathrm{NAD}^{+}\right)$sebagai substrat. Dengan demikian rasio $\mathrm{NAD}^{+} / \mathrm{NADH}$ menurun dan konversi gliseraldehid-3-fosfat menjadi 1,3-bifosfogliserat dihambat, sehingga lebih banyak substrat gliseraldehid-3-fosfat yang akan digunakan untuk sintesis $\alpha$-gliserol fosfat, yaitu prekursor DAG. DAG adalah aktivator PKC yang akan mengatur sintesis dan perpindahan MES. PKC berperan dalam pengendalian transkripsi gen aldose reduktase.

\section{f. Pembentukan reactive oxygen species (ROS)}

Reactive oxygen species menurunkan nitric oxide yang akan mengaktivasi aldose reduktase. Kadar mRNA aldose reduktase dalam sel bersirkulasi meningkat pada nefropati diabetik, tetapi tidak meningkat pada diabetik tanpa nefropati. Pada penelitian terhadap manusia, inhibitor aldose reduktase tidak mempunyai efek atau sedikit mempunyai efek dalam perburukan komplikasi mikrovaskular ginjal. Hipertonisitas merangsang ekspresi gen aldose reduktase. ${ }^{3}$

\section{g. Amadori-glycated albumin}

Pertumbuhan sel ginjal pada hiperglikemia diatur oleh TGF- $\beta$, sistem PKC, dan produksi berlebih MES. Protein amadori-glycated yang lebih dahulu timbul daripada AGEs pada proses glikasi, mempunyai efek yang sama dengan AGEs. Pada sel epitel glomerulus yang terpapar dengan serum terglikasi akan tampak peningkatan kadar laminin dan antigen $\mathrm{MBG}$, penurunan aktivitas kolagenase, sedangkan kolagen tipe I dan fibronektin tidak berubah. Albumin yang terglikasi (glycated albumin) dan glukosa yang tinggi akan meningkatkan TGF- $\beta 1$ dan mRNA reseptor TGF- $\beta$ tipe II. Sel mesangium binatang percobaan yang diinkubasi dalam media glukosa yang mengandung protein serum terglikasi mengalami peningkatan kolagen tipe IV dan mRNA fibronektin. Pada nefropati diabetik kadar albumin amadori plasma lebih tinggi dibandingkan dengan pasien normoalbuminuria. Antibodi terhadap albumin terglikasi dapat mencegah peningkatan fibronektin dan kolagen tipe IV dalam sel glomerulus. ${ }^{3}$

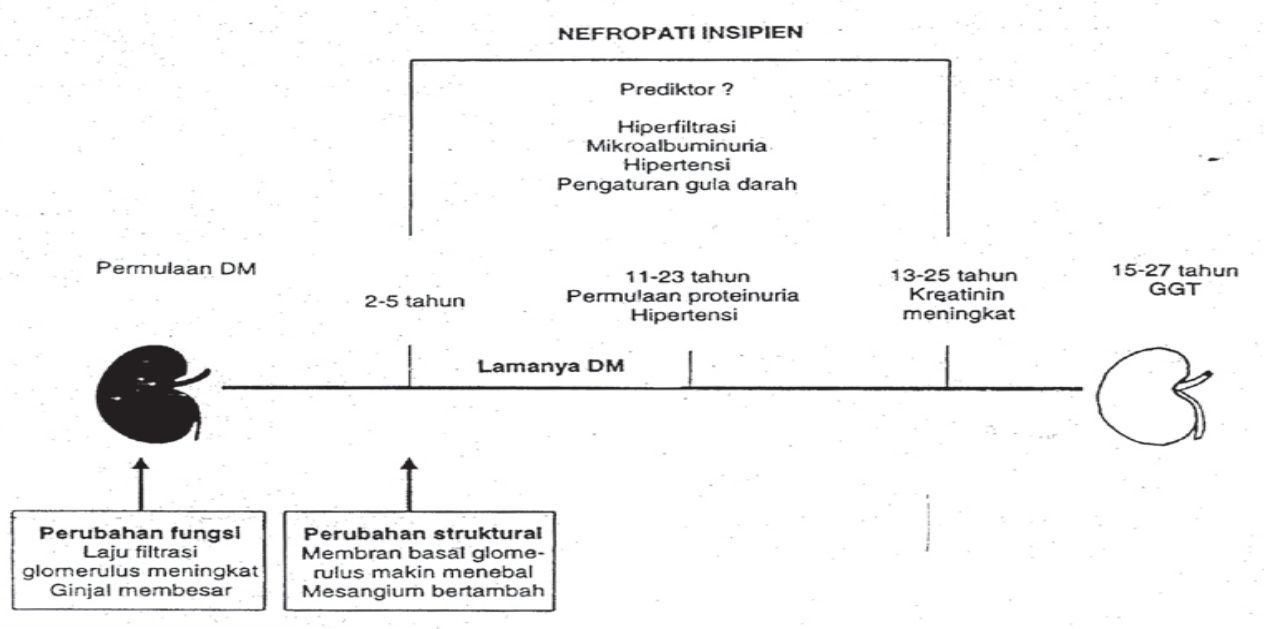

Gambar 2. Perjalanan klinik terjadinya nefropati diabetik.

(Dikutip dari: Breyer JA, Diabetic nephropathy in insulin-dependent diabetes. Am J Kidney Dis, 1992;20:533-47 dan Kosnadi L, nefropati diabetik, Buku ajar nefrologi anak, 2002, h.427-36 ) 
Tabel 1. Stadium nefropati diabetik pada DMTI

\begin{tabular}{|c|c|c|}
\hline Stadium & & Waktu terjadinya \\
\hline Stadium I & Hipertrofi-hiperfungsi dini & Saat diagnosis \\
\hline Stadium II & $\begin{array}{l}\text { Silent stage: ekskresi albumin normal } \\
\text { Terdapat lesi glomerulus (penebalan } \\
\text { membran basalis, ekspansi mesangium) }\end{array}$ & $\begin{array}{l}\text { Terjadi setelah beberapa tahun } \\
\text { menderita diabetes } \\
\text { Dapat berlanjut hingga } \\
\text { puluhan tahun }\end{array}$ \\
\hline Stadium III & $\begin{array}{l}\text { Mikroalbuminuria, } \\
\text { ekskresi albuminuria menetap dan } \\
\text { meningkat tetapi secara klinik tidak ada } \\
\text { proteinuria }\end{array}$ & $\begin{array}{l}\text { Terjadi setelah }>7 \text { tahun men- } \\
\text { derita diabetes melitus }\end{array}$ \\
\hline Stadium IV & $\begin{array}{l}\text { Nefropati diabetik nyata dengan protein- } \\
\text { ura secara klinik }\end{array}$ & $\begin{array}{l}\text { Terjadi setelah }>15-18 \text { tahun } \\
\text { menderita diabetes melitus }\end{array}$ \\
\hline Stadium V & Gagal ginjal stadium akhir & $\begin{array}{l}\text { Terjadi setelah } 25 \text { tahun } \\
\text { menderita diabetes melitus }\end{array}$ \\
\hline
\end{tabular}

Sumber: Mauer dkk, 2001

\section{h. Perubahan proteoglikan glomerulus}

Selektivitas permeabilitas muatan menggambarkan hilangnya proteoglikan anionik yang berperan dalam ekskresi albumin yang bermuatan negatif. Heparan sulfat yaitu komponen utama glikosaminoglikan dalam MBG akan menghambat proliferasi sel mesangium. Hiperglikemia dapat menyebabkan berkurangnya heparan sulfat di ginjal sebagai akibat menurunnya sintesis dan berkurangnya proses sulfation. Berkurangnya heparan sulfat di ginjal menyebabkan berkurangnya sawar muatan elektrostatik MBG, dan menyebabkan pengeluaran albumin ke dalam filtrat glomerulus yang mengakibatkan albuminuria. Percobaan binatang menunjukkan bahwa pemberian heparin subkutan dapat mencegah peningkatan UAER dan penebalan MBG, yang kemungkinan disebabkan oleh induksi sintesis heparan sulfat. Pemberian glikosaminoglikan oral dapat mengurangi proteinuria pada DMTI dan DMTTI. ${ }^{3}$

\section{Perjalanan klinik nefropati diabetik}

Perjalanan klinik nefropati diabetik terjadi dengan lambat. Insidens nefropati diabetik pada anak mencapai puncaknya setelah 15 tahun mengalami DMTI. Insidens albuminuria persisten pada diabetes selama 25 tahun memperlihatkan penurunan kejadian dari 28\% (tahun 1961 hingga 1965) menjadi 5,8\% (tahun1971 hingga 1975). Hal ini menggambarkan pengendalian kadar gula darah yang semakin baik. Pada nefropati diabetik, akan terjadi penurunan
LFG, albuminuria yang meningkat hingga menjadi proteinuria masif, dan berakhir dengan penyakit ginjal stadium akhir.

Keterlibatan ginjal pada DMTI dibagi menjadi 5 stadium berdasarkan derajat penurunan fungsi dan morfologi ginjal.

- Stadium 1 ditandai dengan pembesaran ginjal dan hiperfiltrasi glomerulus, tanpa kelainan histologis pada glomerulus atau struktur vaskular.

- Stadium 2 terjadi 2 hingga 5 tahun dengan kelainan pembesaran ginjal, hiperfiltrasi glomerulus, dan kelainan histopatologis berupa penebalan membran basalis dan ekspansi daerah mesangium. Biopsi ginjal tidak terindikasi pada stadium 2.

- Stadium 3 atau nefropati diabetik insipien disebut juga dengan fase mikroalbuminuria. Umumnya terjadi pada dekade kedua diabetes melitus. Pada stadium ini, fungsi ginjal masih normal dan pemeriksaan urinalisis dengan dipstik tidak menunjukkan proteinuria, tetapi terdapat mikroalbuminuria. LFG mulai menurun apabila ekskresi albumin mencapai $70 \mu \mathrm{l} /$ menit dengan penurunan $3-4 \mathrm{ml} /$ menit/tahun. Pada nefropati stadium 3 ini, tekanan darah sistemik meningkat disertai penurunan LFG yang progresif, anemia dan gangguan keseimbangan homeostasis kalsium-fosfor.

- Stadium 4 adalah nefropati yang ditandai dengan proteinuria positif dengan dipstik, penurunan LFG dengan cepat, hipertensi berat, dan insufisiensi ginjal sedang sampai berat. Stadium ini biasanya terjadi dalam 10 tahun. 
- Stadium 5 adalah nefropati berupa sindrom nefritik dan penyakit ginjal stadium akhir dengan uremia yang memerlukan terapi pengganti dialisis dan transplantasi ginjal. ${ }^{1,2,6}$

\section{Diagnosis}

Diagnosis nefropati diabetik didasarkan pada gambaran klinis. Proteinuria terjadi dengan lambat, mula-mula timbul secara intermitten, kemudian menetap dan meningkat. Awitan terjadinya proteinuria nyata berkaitan dengan hipertensi dan penurunan LFG. ${ }^{1-4}$ Diagnosis DMTI ditentukan dengan pemeriksaan C-peptide serta dengan antibodi terhadap islet cell atau glutamic acid decarboxylase ${ }^{3}$ Pada DMTI yang sudah sakit lebih dari sepuluh tahunan dan mengalami proteinuria nyata $>0,5 \mathrm{~g} / 24$ jam, maka kemungkinan terjadinya nefropati diabetik sangat besar. ${ }^{1-4}$ Bila sudah terjadi retinopati dan penyebab proteinuria lainnya dapat disingkirkan, maka tidak perlu dilakukan biopsi ginjal sebab pada 95\% DMTI dengan retinopati dan proteinuria terdapat nefropati diabetik. Biopsi ginjal terindikasi pada nefropati diabetik dengan perjalanan klinik yang atipik, seperti pada proteinuria dan penurunan fungsi ginjal yang progresif cepat, awitan penyakit ginjal yang terjadi dalam 10 tahun, atau jika riwayat penyakit dan gambaran laboratorium tidak sesuai. $^{3}$

\section{Tata laksana}

\section{Deteksi nefropati diabetik dan penanggulangan mikroalbuminuria}

Deteksi dini nefropati diabetik dilakukan dengan pemeriksaan mikroalbuminuria, dan merupakan prosedur rutin dalam penanganan diabetes melitus. The American Diabetes Association (ADA) merekomendasikan pemeriksaan mikroalbuminuria setiap tahun pada DMTI dan DMTTI setelah 5 tahun menderita sakit. ${ }^{1}$ Pada DMTI dengan lama sakit lebih dari 5 tahun harus dilakukan pemeriksaan UAER dengan pemeriksaan urin 24 jam atau pemeriksaan rasio albumin/kreatinin pada urin pagi hari. Jika UAER mencapai $20 \mu \mathrm{g} /$ menit (30 mg/hari), atau rasio albumin/kreatinin $>30 \mu \mathrm{g} / \mathrm{mg}$, pemeriksaan tersebut harus diulang 3-6 bulan kemudian untuk mendiagnosis mikroalbuminuria. Jika hasil pemeriksaan ulangan menunjukkan hasil <20 $\mu \mathrm{g} /$ menit, pasien diperlakukan sebagai pada tahap awal. Jika hasil pemeriksaan UAER menunjukkan peningkatan, terindikasi pemberian penghambat ACE untuk menghambat progresivitas nefropati. ${ }^{1,2,3}$ Ketoasidosis, diuretik, penyakit akut, penyakit jantung, infeksi saluran kemih, menstruasi, hipertensi berat, kontrol gula darah yang buruk, latihan berat, dan berbagai penyakit ginjal nondiabetik dapat menyebabkan pengeluaran albumin..$^{1,2,3}$ Oleh sebab itu pemeriksaan UAER perlu diulang 3-6 bulan kemudian agar mikroalbuminuria yang terjadi diyakini karena nefropati diabetik dan bukan oleh sebab lain. ${ }^{2}$

Setelah diagnosis mikroalbuminuria ditegakkan, dilakukan tata laksana terhadap efek hiperfiltrasi ginjal, yaitu 1. mengontrol hiperglikemia, 2. mengontrol hipertensi dengan agresif, 3 . pengontrolan selektif terhadap dilatasi arteriol dengan memberikan penghambat ACE untuk menurunkan tekanan transglomerulus kapiler, dan 4. restriksi protein diet (sebab asupan tinggi protein akan menyebabkan peningkatan perfusi ginjal). ${ }^{1}$

Mikroalbuminuria persisten atau yang tidak berkurang dengan pengontrolan gula darah, terindikasi untuk pemberian penghambat ACE. ${ }^{2}$ Penghambat ACE dapat menurunkan tekanan kapiler glomerulus tetapi tidak dapat mencegah penebalan MBG. Angiotensin dapat bekerja sebagai growth factor terhadap sel mesangium dan otot polos dan merangsang sintesis fibronektin sel mesangium. Meningkatnya produksi fibronektin sel mesangium pada keadaan hiperglikemia dapat dihambat oleh penghambat ACE kaptopril. Peningkatan produksi kolagen sel mesangium akibat stimulasi glukosa dapat dihambat oleh enapril. Kaptopril dapat menghambat MMPs 72-kd dan $92 \mathrm{kd}$, kolagenase tipe IV, sehingga menyebabkan penimbunan MES. Lisinopril yaitu penghambat ACE nonsulfhidril akan menghambat metalloproteinase dan efeknya lebih besar dibandingkan kaptopril. ${ }^{3}$

Berbagai penelitian membuktikan bahwa penghambat ACE akan memperlambat progresivitas nefropati diabetik, dan mengurangi kerusakan glomerulus dengan mempertahankan tekanan kapiler glomerulus dalam keadaan normal. ${ }^{2}$ Lewis dkk. ${ }^{7}$ melaporkan penelitian kolaboratif multisenter dengan metode acak prospektif mengenai efek penghambat ACE terhadap nefropati diabetik. Sebanyak 409 pasien DMTI dengan lama sakit minimal 7 tahun, kreatinin serum $\leq 2,5 \mathrm{mg} / \mathrm{dL}$, dan proteinuria $>500 \mathrm{mg} /$ hari. 
Pemberian kaptopril menurunkan proteinuria, angka kematian, dialisis, dan transplantasi ginjal. Sebanyak $64 \%$ pasien meninggal dan $61 \%$ menjalani dialisis dan atau transplantasi ginjal berasal dari kelompok plasebo. Disimpulkan bahwa kaptopril secara bermakna menurunkan laju penurunan fungsi ginjal pada nefropati diabetik stadium $4 .^{7}$ Inserra dkk. ${ }^{8}$ melaporkan bahwa pemberian penghambat ACE enalapril pada nefropati diabetik insipien dan pasca latihan menyebabkan penurunan UAER secara bermakna.

Committee of the Council on Diabetes Mellitus of the National Kidney Foundation merekomendasikan pemantauan terhadap pemberian penghambat ACE pada nefropati diabetik sebagai berikut: a.) ukur UAER setiap 6 bulan, b.) periksa kadar kreatinin dan kalium serum 7-10 hari setelah terapi dimulai dan kemudian diperiksa minimal setiap 3 bulan. c.) periksa darah tepi setiap 3 bulan. Jika terdapat peningkatan kadar kreatinin serum $0,5 \mathrm{mg} / \mathrm{dL}$ atau kalium $\geq 5 \mathrm{mEq} / \mathrm{L}$, pasien dirujuk ke nefrologis. Pemberian penghambat ACE dimulai dengan dosis yang paling rendah dan dinaikkan secara bertahap sesuai dengan keadaan. Jika mikroalbuminuria menurun dengan penghambat ACE dosis rendah dan tekanan darah serta kreatinin serum stabil, maka dosis obat tidak perlu diubah. Jika mikroalbuminuria makin bertambah, maka dosis obat perlu disesuaikan. ${ }^{10}$ Kaptopril biasanya diberikan dengan dosis $0,3-2 \mathrm{mg} / \mathrm{kgbb} /$ hari dengan dosis maksimal $5 \mathrm{mg} / \mathrm{kgbb} /$ hari. Enalapril diberikan dengan dosis 0,1 dan maksimal $1 \mathrm{mg} / \mathrm{kgbb} / \mathrm{hari}$. Lisinopril diberikan dengan dosis 0,1 dan maksimal $1 \mathrm{mg} / \mathrm{kgbb} / \mathrm{hari}$.

Pada DMTTI, pemberian antagonis reseptor angiotensin II dapat melindungi ginjal (renal protective) tanpa mempengaruhi tekanan darah, sedangkan pemberian penghambat ACE tidak direkomendasikan. Meskipun terdapat penelitian yang membuktikan manfaat pemberian antagonis reseptor angiotensin II pada DMTI, namun obat ini baru digunakan apabila pasien tidak tolerans terhadap penghambat ACE, misalnya terjadi efek samping berupa batuk. ${ }^{2}$

\section{Kontrol tekanan darah}

Pengendalian tekanan darah yang efektif akan memperlambat penurunan LFG dan progresivitas terjadinya penyakit ginjal kronik. Berbagai penelitian telah membuktikan efektivitas antihipertensi memperlambat terjadinya nefropati diabetik. ${ }^{2}$ Untuk menanggulangi hipertensi, terapi inisial yang direkomendasikan adalah penghambat ACE. Pada pemberian penghambat ACE, perlu diwaspadai terjadinya penurunan fungsi ginjal akut dan hiperkalemia. Hiperkalemia dapat terjadi karena insufisiensi ginjal atau hipoaldosteronism hiporeninemia. Sebagai antihipertensi pilihan kedua adalah diuretik dosis rendah, penghambat reseptor $\alpha(\alpha$-receptor blocker), dan calsium channel blocker. Diuretik efektif untuk menurunkan tekanan darah dan bekerja secara sinergistik dengan penghambat ACE. Pemberian nifedipin dapat menyebabkan penurunan kadar insulin sehingga menimbulkan peningkatan kadar gula darah. ${ }^{2}$ Pada DMTI, $\beta$ blockers dan potassium sparing diuretics sebaiknya dihindari atau kalau diberikan perlu perhatian khusus. $\beta$ blockers seperti propranolol dapat meyulitkan pengontrolan kadar gula darah, menghambat terjadinya hipoglikemia dan memperlambat penyembuhan, menimbulkan efek yang tidak baik terhadap metabolisme lipoprotein, serta menyebabkan hiperkalemia ${ }^{2}$ Pada diabetes melitus dengan normoalbuminuria dan normotensi, peningkatan tekanan darah sistolik pada malam hari dapat menyebabkan mikroalbuminuria. Pada pasien seperti ini, dapat diberikan penghambat ACE sebelum terjadi nefropati insipien. ${ }^{10}$

\section{Penanggulangan diabetes}

Tata laksana diabetes melitus meliputi pengontrolan gula darah, perbaikan kebiasaan hidup, pemberian insulin, dan program latihan. Pengontrolan gula darah terbukti dapat menurunkan kejadian albuminuria, mencegah penurunan LFG dan terjadinya nefropati. Mempertahankan keadaan metabolik dalam keadaan normal dapat mencegah kerusakan vaskular. Perlu dilakukan pemantauan gula darah (home glucose monitoring) dan mengukur hemoglobin glikosilat atau HbA1C. ${ }^{1,2,3}$.

Pengendalian kadar glukosa darah terbukti menurunkan komplikasi mikrovaskular. Pada DMTI, kontrol gula darah yang efektif dan kadar hemoglobin glikosilat yang normal menurunkan risiko terjadinya mikroalbuminuria, menurunkan risiko terjadinya hipertensi, dan memperlambat progresivitas nefropati atau GGT. ${ }^{2}$ The Diabetes Control and Complications Trial (DCCT) (1993) melaporkan bahwa setelah 9 tahun, dengan pencegahan primer kejadian mikroalbuminuria sebesar $16 \%$, lebih rendah dibandingkan dengan tanpa pencegahan primer yaitu $27 \%$. Setelah 9 tahun, insidens mikroalbuminuria pada kelompok yang 
mendapat pencegahan sekunder adalah 26\% sedangkan pada kelompok yang mendapat terapi konvensional adalah 42\%. Progresivitas terjadinya penyakit ginjal kronik atau GGT lebih rendah pada pasien dengan kontrol gula darah yang intensif dibandingkan dengan yang tidak intensif. ${ }^{11}$

\section{Penutup}

Tata laksana nefropati diabetik pada anak membutuhkan dedikasi yang tinggi dari tim pemelihara kesehatan interdisiplin seperti dokter umum, endokrinologis anak, nefrologis anak, ahli gizi, optalmologis, dan pekerja sosial.

\section{Daftar Pustaka}

1. Alemzadeh R, Wyatt DT. Diabetes mellitus in children. Dalam: Behrman, RE, Kliegman RM, Jenson HB, penyunting. Nelson textbook of pediatrics. Edisi ke-17, Philadelphia: Saunders; 2004.h.1947-71.

2. Feld LG. Diabetic nephropathy. Dalam: Avner ED, Harmon WE, Niaudet P, penyunting. Pediatric Nephrology. Edisi ke-5, Philadelphia: Lippincott Williams \& Wilkins; 2004.h.931-9.

3. Mauer M, Fioretto P, Woredekal Y, Friedman EA. Diabetic nephropathy. Dalam: Schrier RW, penyunting, Diseases of the kidney and urinary tract. Edisi ke-7, Philadelphia: Lippincott Williams \& Wilkins; 2001.h. 2083-128.

4. Webb NJA, Brogan PA, Baildam EM. Diabetes mellitus.
Dalam: Webb NJA, Postlethwaite RJ, penyunting, Clinical paediatric nephrology. Edisi ke-3, New York: Oxford University Press; 2003.h.398-403.

5. Kosnadi L. Nefropati diabetik. Dalam: Alatas H, Tambunan T, Trihono PP, Pardede SO, penyunting. Buku ajar nefrologi anak. Edisi ke-2, Jakarta: Ikatan Dokter Anak Indonesia; 2002. h.427-36.

6. Breyer JA, Diabetic nephropathy in insulin-dependent diabetes. Am J Kidney Dis 1992;20:533-47.

7. Lewis EJ, Hunsiker LG, Bain RP. The Collaborative Study Group: the effect of angiotensin-convertingenzyme inhibition on diabetic nephropathy. N Engl J Med 1993;329:1456-62.

8. Inserra F, Daccordi H, Ippolito JL. Decreased of excercise-induced microalbuminuria in patients with type I diabetes by means of an angiotensin-converting enzyme inhibitor. Am J Kidney Dis 1996:27:26-33.

9. Bennett PH, Haffner S, Kasiske BL. Screening and management of microalbuminuria in patients with diabetes mellitus. Recommendations to the Scientific Advisory Board of the National Kidney Foundation from an Ad Hoc Committee of the Council on Diabetes Mellitus of the National Kidney Foundation. Am J Kidney Dis 1995;25:107-12.

10. Ingelfinger JR, Ambulatory blood-pressure monitoring as a predictive tool. New Engl J Med 2002; 347: 778-9.

11. Diabetes Control and Complications Trial Research Group. The effect of intensive treatment of diabetes on the development and progression of long-term complications in insulin-dependent diabetes mellitus. N Engl J Med 1993;329:977-86. 